\title{
Farinose alpine Primula species: Phytochemical and morphological investigations
}

\author{
Paola S. Colombo ${ }^{\mathrm{a}, \mathrm{e}}$, Guido Flamini ${ }^{\mathrm{b}}$, Michael S. Christodoulou ${ }^{\mathrm{c}}$, Graziella Rodondi ${ }^{\mathrm{d}}$, Sara Vitalini ${ }^{\mathrm{a}, \mathrm{e}}$, \\ Daniele Passarella ${ }^{c}$, Gelsomina Fico ${ }^{\mathrm{a}, \mathrm{e}, *}$ \\ a Dipartimento di Scienze Farmaceutiche, Università degli Studi di Milano, via Mangiagalli 25, 20133 Milano, Italy \\ ${ }^{\mathrm{b}}$ Dipartimento di Farmacia, Università degli Studi di Pisa, via Bonanno 33, 56126 Pisa, Italy \\ ${ }^{c}$ Dipartimento di Chimica, Università degli Studi di Milano, via Golgi 19, 20133 Milano, Italy \\ ${ }^{\mathrm{d}}$ Dipartimento di Bioscienze, Università degli Studi di Milano,via Celoria 26, 20133 Milano, Italy \\ e Orto Botanico G.E. Ghirardi, Dipartimento di Scienze Farmaceutiche, Via Religione 25, Toscolano Maderno, Brescia, Italy
}

\section{A R T I C L E I N F O}

Article history:

Received 30 July 2013

Received in revised form 20 November 2013

Available online 14 December 2013

\section{Keywords:}

Primula albenensis, P. auricula, P. farinosa, P.

halleri

Primulaceae

Phytochemistry

Trichome micromorphology

Farina

Flavonoids

Volatile compounds

\begin{abstract}
A B S T R A C T
This work investigated the epicuticular and tissue flavonoids, the volatiles and the glandular trichome structure of the leaves of four species of Primula L. that grow in the Italian Eastern Alps. Primula albenensis Banfi and Ferlinghetti, P. auricula L., P. farinosa L., P. halleri Gmelin produce farinose exudates that are deposited on the leaf surface as filamentous crystalloids.

In addition to compounds already known, a new flavone, the 3,5-dihydroxyflavone, was isolated from the acetone extract of leaf farinas and three new flavonol glycosides, $3^{\prime}-O$-( $\beta$-galactopyranosyl)-2'-hydroxyflavone, isorhamnetin 3-O- $\alpha$-rhamnopyranosyl- $(1 \rightarrow 3)-O$ - $[\alpha$-rhamnopyranosyl- $(1 \rightarrow 6)]-O$ - $\beta$-galactopyranoside, quercetin $3-0$ - $\alpha$-rhamnopyranosyl- $(1 \rightarrow 3)-0$-[ $\alpha$-rhamnopyranosyl- $(1 \rightarrow 6)]-0$ - $\beta$-galactopyranoside, were isolated from the $\mathrm{MeOH}$ extract of the leaves. All the structures were elucidated on the basis of their ${ }^{1} \mathrm{H}$ and ${ }^{13} \mathrm{C}$ NMR data and 2D NMR techniques, as well as on HPLC-MS. The leaf-volatiles emitted by these Primula species were mainly sesquiterpene hydrocarbons, with the exception of $P$. albenensis, which produced almost exclusively a non-terpene derivative; $P$. halleri flowers were also examined and the volatiles emitted by the flower parts (corolla and calyx) were compared with the corresponding leaves.
\end{abstract}

(c) 2013 Elsevier Ltd. All rights reserved.

\section{Introduction}

The genus Primula L. belongs to the Primulaceae family and includes more than 400 species of both annual and perennial herb plants distributed in temperate and cold regions of the Northern hemisphere and in tropical mountains. All the species are characterised by a rosette of sessile or petioled basal leaves. The flowers, usually on top of a scape, are gathered in large or contracted/capituliform umbels. The fruits are usually indehiscent capsules containing many seeds. The glands of some Primula species produce farinas and/or exudates. The species studied are the only alpine Primula taxa living on Italian territory that show a leaf farina deposit (Banfi and Ferlinghetti, 1993; Pignatti, 1982).

The relation between glandular trichome morphology and exudate type has been previously investigated by Bhutia et al., 2012; Fico et al., 2007; Higuchi et al., 1999; Vitalini et al., 2011.

\footnotetext{
* Corresponding author. Tel.: +39 0250319375; fax: +39 0250314764.

E-mail addresses: paola.colombo6@studenti.unimi.it (P.S. Colombo), flamini@ farm.unipi.it (G. Flamini), michael.christodoulou@unimi.itc (M.S. Christodoulou) graziella.rodondi@unimi.it (G. Rodondi), sara.vitalini@unimi.it (S. Vitalini), daniele. passarella@unimi.it (D. Passarella),gelsomina.fico@unimi.it (G. Fico).
}

Most of the available literature on Primula species phytochemistry explores the activities of the saponins, which can be found particularly in the hypogeal parts, because they are the compounds with the main known pharmacological properties (Ahmad et al., 1993; Calis, 1992; Coran and Mulas, 2012; Della Loggia, 1993; Morozowska and Wesołowska, 2004; Müller et al., 2006; Okršlar et al., 2007).

Flavonoid content of some Primula species have been investigated in previous studies: Primula vulgaris (Harborne, 1968); P. pulverulenta (Wollenweber et al., 1988a, 1989); P. polyantha (Saito et al., 1990); P. macrophylla (Ahmad et al., 1991); P. officinalis (Karl et al., 1981); P. elatior (Petitjean-Freytet, 1993); P. faberi (Zhang et al., 1993); P. denticulata (Tokalov et al., 2004; Wollenweber et al., 1990); P. veris (Budzianowski et al., 2005; Huck et al., 1999, 2000); P. hirsuta, P. auricula and P. daonensis (Fico et al., 2007); P. maximowiczii (Qu et al., 2008); P. spectabilis (Vitalini et al., 2011); exudate flavonoids of Primula spp. (Bhutia et al., 2011, 2012, 2013; Bhutia and Valant-Vetschera, 2012; ValantVetschera et al., 2009).

Data from literature show that Primula genus is characterised by mono-, di- and triglycosylated flavonols, which glycone consists 
mainly of galactose, glucose, and rhamnose linked to the aglycone preferentially in 3-position. Flavonoids in the free form, mainly flavones and flavonols, are present as well.

The aim of this work is the characterisation of the four species through the analysis of epicuticular and tissue flavonoids, volatile compounds and glandular trichome morphology of the leaves. The volatile compounds emitted by the flower (calyx and corolla) of $P$. halleri were also studied.

\section{Results}

\section{Glandular trichomes, morphology and distribution}

In $P$. albenensis, sparse glandular hairs may cover the entire leaf on both surfaces, producing a thin cover of farina. In $P$. auricula, glandular hairs can be mainly found on the leaf margin. The farinose exudates of both $P$. albenensis and $P$. auricula are white. In $P$. farinosa and $P$. halleri, glandular hairs can be found only on the lower surface of the leaf. In both species, the exudates form a thick coating, respectively white and yellow.

Under the scanning electron microscope (SEM), the glandular hair morphology is completely masked by the extruded farina that appears deposited around the gland of each trichome, in the shape of needles randomly extruded (Fig. 1A-D).

Under the light microscope (LM), fully developed capitate trichomes show an unicellular glandular head and a monoseriate stalk, which consists of a rectangular neck and a cylindrical/conical base (Fig. 1E-H). In P. albenensis, the lower stalk cell is cylindrical and very long (about $130 \mu \mathrm{m}$ ), and the secretory head is bulb-shaped (about 35 per $25 \mu \mathrm{m}$ ) (Fig. 1E). In P. auricula the lower stalk cell is conical/pyramidal, about $40 \mu \mathrm{m}$ long, and the head is round, about $35 \mu \mathrm{m}$ in diameter (Fig. 1F). P. farinosa and P. halleri have short-stalked capitate trichomes with a very short conical stalk cell and a globoid head. The glandular head of P. halleri (about 25$30 \mu \mathrm{m}$ in diameter) is twice as big as that of $P$. farinosa (about $15-20 \mu \mathrm{m}$ in diameter) (Fig. $1 \mathrm{G}$ and $\mathrm{H}$ ).

\section{Isolation and identification of epicuticular flavonoids}

Nine flavones were isolated from the leaf farina acetone extract of the four species: the new compound 3,5-dihydroxyflavone (1) in $P$. farinosa and the already known flavone (2) (Weller et al., 1953), 5-hydroxyflavone (primuletin) (3) (Geissman, 1962), 5,7-dihydroxyflavone (chrysin) (4) (in Pinus spp., Lindstedt, 1949a,b, 1950), 7,8-dihydroxyflavone (5) (in Tridax procumbens, Abubakar et al., 2012), 2'-hydroxyflavone (6) (Bouillant et al., 1971), 4'-hydroxyflavone (7) (in Sophora spp., Ruiz et al., 1999), 2',5'-dihydroxyflavone (8) (Wollenweber et al., 1988b), 5,8-dihydroxyflavone (primetin) (9) (Tokalov et al., 2004).

The ${ }^{13} \mathrm{C}$ NMR spectrum of compound (1) showed 13 signals, sorted by DEPT experiments into $6 \mathrm{CH}$ and 7 quaternary $\mathrm{C}$. In the ${ }^{1} \mathrm{H}$ NMR spectrum obtained in DMSO- $d_{6}$, a $1-\mathrm{H}$ singlet was present at $\delta 12.53$, indicating the presence of an unsubstituted $\mathrm{OH}$ linked to the C-5 carbon. Furthermore, a two-proton double doublet $(\delta 8.16, J=6.6$ and $1.8 \mathrm{~Hz}$ ) and a three-proton multiplet suggested the presence of an unsubstituted B-ring of a flavonoid. The A-ring was substituted only on the $C-5$ because of the typical proton pattern signals: two doublets $(\delta 6.65$ and $7.25, J=8.8 \mathrm{~Hz})$ and a double doublet $(\delta 7.09, J=8.8$ and $8.8 \mathrm{~Hz}$ ), all integrating for one proton. These data permitted to identify compound (1) as 3,5-dihydroxyflavone; the identification was confirmed by ${ }^{13} \mathrm{C}$ NMR data (Table 1 ). Compounds 2-9 were identified by NMR and ESI-MS experiments and compared to literature data (Table 1).

\section{Isolation and identification of tissue flavonoids}

Three compounds were isolated from the $\mathrm{MeOH}$ leaf extract of $P$. farinosa ( $30 \mathrm{~g}$ of dried leaves $/ 5.1 \mathrm{~g}$ of extract): the new flavonol glycoside 3'-O-( $\beta$-galactopyranosyl)-2'-hydroxyflavone $\left(t_{R} 18.81\right.$, $8.2 \mathrm{mg}$ ) (10); the known compound kaempferol 3-O- $\alpha$-rhamnopyranosyl-( $1 \rightarrow 3)-O$-[ $\alpha$-rhamnopyranosyl- $(1 \rightarrow 6)]-O$ - $\beta$-galactopyranoside $\left(t_{R} 15.55,4.8 \mathrm{mg}\right)(\mathbf{1 1})$, never found in Primula genus before; and clitorin $\left(t_{R} 20.55 ; 5.6 \mathrm{mg}\right)(\mathbf{1 2})$, which is quite a widespread compound in nature and had already been isolated from Primula maximowiczii (Qu et al., 2008).

Two new flavonol glycosides were isolated from the MeOH leaf extract of $P$. halleri ( $20 \mathrm{~g}$ of dried leaves $/ 3 \mathrm{~g}$ of extract): isorhamnetin 3-O- $\alpha$-rhamnopyranosyl- $(1 \rightarrow 3)-O$-[ $\alpha$-rhamnopyranosyl-( $1 \rightarrow 6)]$ - $O$ - $\beta$-galactopyranoside $\left.\left(t_{R} 19.27,4.9 \mathrm{mg}\right)(\mathbf{1 3})\right)$ and quercetin $3-0$ - $\alpha$-rhamnopyranosyl- $(1 \rightarrow 3)-0$-[ $\alpha$-rhamnopyranosyl- $(1 \rightarrow 6)]-O$ - $\beta$-galactopyranoside $\left(t_{R} 13.51,5.3 \mathrm{mg}\right)(\mathbf{1 4})$. From the same extract kaempferol 3-O- $\beta$-glucopyranosyl- $(1 \rightarrow 2)$ gentiobioside ( $t_{R} 12.48,5.6 \mathrm{mg}$ ) (15), an already known flavonol glycoside, was also isolated.

The known flavonol glycoside $4^{\prime}-0$-( $\beta$-glucopyranosyl)-3'hydroxyflavone $\left(t_{R} 20.19,10.5 \mathrm{mg}\right)(\mathbf{1 6})$ was found in the $\mathrm{MeOH}$ leaf extract of $P$. albenensis.

The structural elucidation of these compounds was deduced on the basis of their ${ }^{1} \mathrm{H}$ and ${ }^{13} \mathrm{C}$ NMR data, including those derived from 2D-NMR, as well as from HPLC-MS results.

Compound 10 was obtained as an amorphous white solid. The negative ESI-MS spectrum returned a quasimolecular peak at $\mathrm{m} / \mathrm{z}$ $415.3[\mathrm{M}-\mathrm{H}]^{-}$and a fragment at $m / z$ 253.2. The loss of 162 mass units from the molecular ion and a signal at $\delta 61.69 \mathrm{ppm}$, shown by APT to represent a $\mathrm{CH}_{2}$ group, suggested a sugar moiety. The NMR spectrums were obtained in $\mathrm{CD}_{3} \mathrm{OD}$ in order to avoid the overlap between the protons of the sugar moiety and the protons related to the water of DMSO- $d_{6}$. The combination of ${ }^{1} \mathrm{H}$ NMR, COSY, HMBC, HSQC and NOESY experiments presented a typical flavonoid pattern related to $2^{\prime}, 3^{\prime}$-disubstituted-flavone. HMBC signal between proton $\mathrm{H}-1^{\prime \prime}$ of the sugar moiety and $\mathrm{C}-3^{\prime}$ of the flavonoid skeleton indicated the presence of the sugar unit to $\mathrm{C}-3^{\prime}$ of the aglycone and the $\mathrm{OH}$-group at position $2^{\prime}$. The signal in ${ }^{1} \mathrm{H}$ NMR spectrum at $4.98 \mathrm{ppm}$ was assigned to the anomeric proton $\left(\mathrm{H}-1^{\prime \prime}\right)$ with a coupling constant $J=7.9 \mathrm{~Hz}$ indicating a $\beta$-configuration. NOE signals between $\mathrm{H}-1^{\prime \prime}$ and $\mathrm{H}-3^{\prime \prime}, \mathrm{H}-1^{\prime \prime}$ and $\mathrm{H}-5^{\prime \prime}$, and $\mathrm{H}-3^{\prime \prime}$ and $\mathrm{H}-4^{\prime \prime}$ of the sugar moiety indicated the presence of a $\beta$-galactose. Therefore, compound $\mathbf{1 0}$ was identified as $3^{\prime}-O-(\beta$-galactopyranosyl)-2'-hydroxyflavone (Table 2 ).

On the basis of its NMR data, compound $\mathbf{1 1}$ was identified as kaempferol 3-O- $\alpha$-rhamnopyranosyl- $(1 \rightarrow 3)$-[ $\alpha$-rhamnopyrano$\operatorname{syl}(1 \rightarrow 6)]-0$ - $\beta$-galactopyranoside, previously isolated by Jasminum officinale L. var. grandiflorum (Zhao et al., 2007) (Table 2).

Compound 12 was identified as clitorin (Kazuma et al., 2003; Nahrstedt et al., 2006) (Table 2).

Compound 13 was obtained as a yellowish powder that appeared on TLC as a yellow spot after treatment with Naturstoffreagenz A-PEG. The negative ESI-MS spectrum showed a quasimolecular peak $[\mathrm{M}-\mathrm{H}]^{-}$at $769 \mathrm{~m} / z$, corresponding to the molecular formula $\mathrm{C}_{34} \mathrm{H}_{42} \mathrm{O}_{20}$. The ${ }^{13} \mathrm{C}$ NMR spectrum showed 31 signals, sorted by DEPT experiments into $20 \mathrm{CH}, 1 \mathrm{CH}_{2}, 3 \mathrm{CH}_{3}$ and 10 quaternary $\mathrm{C}$. In the ${ }^{1} \mathrm{H}$ NMR spectrum obtained in DMSO- $d_{6}$, a three-proton ABM system was present $(\delta 7.92, \mathrm{~d}, J=1.8 \mathrm{~Hz} ; 7.39$, dd, $J=8.8$ and $1.8 \mathrm{~Hz} ; 6.80, \mathrm{~d}, J=8.8 \mathrm{~Hz}$ ), typical of a $3^{\prime}, 4^{\prime}$-disubstituted ring B of a flavonoid nucleus. Ring A showed two coupled doublets $(\delta 6.08$ and $6.29, \mathrm{~d}, J=1.8 \mathrm{~Hz}$ ), due to the two meta-related $\mathrm{H}-6$ and $\mathrm{H}-8$ protons. Moreover, a three-proton singlet was present at $\delta 3.80$, indicating the presence of an aromatic methoxyl group. The linkage of this group on the carbon $3^{\prime}$ was confirmed by the typical shifts experienced by the other carbons of ring B and by HMBC experiments. 

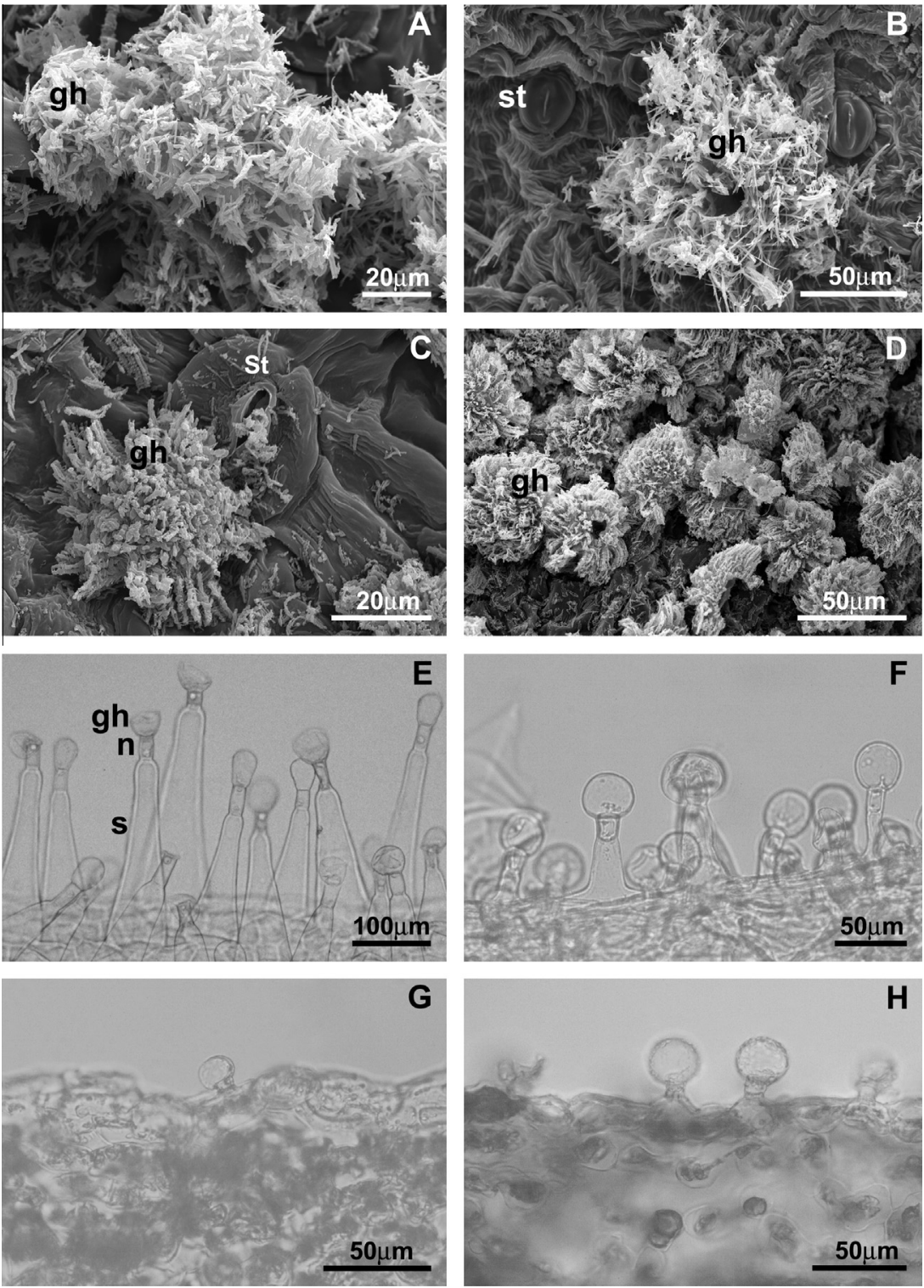

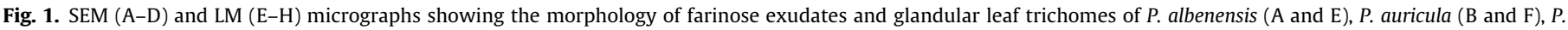
farinosa (C and G) and P. halleri (D and H). Abbreviations: n, neck; gh, glandular head; s, stalk; st, stoma.

These data are consistent with a isorhamnetin skeleton. Furthermore, the signals of three anomeric sugar protons were clearly visible as two broad singlets at $\delta 4.71$ and 4.40 and as a doublet $(J=7.3 \mathrm{~Hz})$ at $\delta 5.25$. At higher fields, two three-proton doublets $(\delta$ $1.06, J=5.9$ and $\delta 0.98, J=6.1 \mathrm{~Hz}$ ) were present. This situation led us to hypothesize the presence of two deoxysugars. Analysis of the ${ }^{13} \mathrm{C}$ NMR spectrum permitted us to identify the three sugar units as two $\alpha$-rhamnopyranose residues and a $\beta$-galactopyranose one. By HMBC experiments, it was possible to determine position 3 as the glycosilation site of the trisaccharide moiety and to determine the relative linkage sites of the sugar units. NMR data of the sugar moiety were practically identical with those of compound $\mathbf{1 1}$. Therefore, compound 13 was identified as isorhamnetin 3-O- $\alpha$-rhamnopyranosyl-( $1 \rightarrow 3)-O$-[ $\alpha$-rhamnopyranosyl- $(1 \rightarrow 6)]-O$ - $\beta$-galactopyranoside, a new natural compound (Table 2 ).

Compound 14 showed the same NMR data as above for its sugar moiety and a very similar pattern for the aglycone part. The most notable difference, apart from some shifts in the position of the signal of ring B carbons, was the lack of the methoxyl resonance. This permitted to identify its structure as quercetin 3-O- $\alpha$-rhamnopyranosyl-( $1 \rightarrow 3)-0$-[ $\alpha$-rhamnopyranosyl- $(1 \rightarrow 6)]$ - $\beta$-galactopyranoside, a new natural product, also confirmed by 2D-NMR data (Table 2).

According to its NMR data, compound $\mathbf{1 5}$ was identified as kaempferol 3-O- $\beta$-glucopyranosyl- $(1 \rightarrow 2)$ gentiobioside, already isolated from Primula maximowiczii (Qu et al., 2008) (Table 2).

Compound 16 was identified as $4^{\prime}-O$-( $\beta$-glucopyranosyl)-3'hydroxyflavone on the basis of its NMR data. This flavonoid had been previously isolated from P. faberi (Zhang et al., 1993).

In these three species with farina, 3-O-glycosides of kaempferol, isorhamnetin and quercetin are present in the tissues. The sugar moiety consists of trisaccharides based on glucose, rhamnose, and galactose. Monoglycosides of $2^{\prime}$ or $3^{\prime}$ hydroxyflavone (Table 2) are also present; glucose is linked in position $4^{\prime}$ or $3^{\prime}$, respectively. These compounds are shown in Table 2 in comparison with those obtained from P. auricula in our previous work (Fico et al., 2007).

\section{Volatile compounds}

The volatile compounds emitted by the four Primula species leaves were investigated, as well as the volatile compounds emitted by the flower (corolla and calyx) of P. halleri. 
Table 1

Epicuticular flavonoids of Primula species.<smiles>[R]c1cc(-c2oc3c([R8])c([R])cc([R6])c3c(=O)c2[R1])c([R2])c([R5])c1[R4]</smiles>

\begin{tabular}{|c|c|c|c|c|c|c|c|c|c|}
\hline Species & Ref. num. & $\mathrm{R}_{1}$ & $\mathrm{R}_{2}$ & $\mathrm{R}_{3}$ & $\mathrm{R}_{4}$ & $\mathrm{R}_{5}$ & $\mathrm{R}_{6}$ & $\mathrm{R}_{7}$ & $\mathrm{R}_{8}$ \\
\hline P. farinosa & 1 & $\mathrm{OH}$ & $\mathrm{H}$ & $\mathrm{H}$ & $\mathrm{H}$ & $\mathrm{H}$ & $\mathrm{OH}$ & $\mathrm{H}$ & $\mathrm{H}$ \\
\hline $\begin{array}{l}\text { P. albenensis } \\
\text { P. auricula } \\
\text { P. farinosa } \\
\text { P. halleri }\end{array}$ & 2 & $\mathrm{H}$ & $\mathrm{H}$ & $\mathrm{H}$ & $\mathrm{H}$ & $\mathrm{H}$ & $\mathrm{H}$ & $\mathrm{H}$ & $\mathrm{H}$ \\
\hline $\begin{array}{l}\text { P. halleri } \\
\text { P. farinosa }\end{array}$ & 3 & $\mathrm{H}$ & $\mathrm{H}$ & $\mathrm{H}$ & $\mathrm{H}$ & $\mathrm{H}$ & $\mathrm{OH}$ & $\mathrm{H}$ & $\mathrm{H}$ \\
\hline P. halleri & 4 & $\mathrm{H}$ & $\mathrm{H}$ & $\mathrm{H}$ & $\mathrm{H}$ & $\mathrm{H}$ & $\mathrm{OH}$ & $\mathrm{OH}$ & $\mathrm{H}$ \\
\hline P. halleri & 5 & $\mathrm{H}$ & $\mathrm{H}$ & $\mathrm{H}$ & $\mathrm{H}$ & $\mathrm{H}$ & $\mathrm{H}$ & $\mathrm{OH}$ & $\mathrm{OH}$ \\
\hline $\begin{array}{l}\text { P. albenensis } \\
\text { P. auricula } \\
\text { P. farinosa } \\
\text { P. halleri }\end{array}$ & 6 & $\mathrm{H}$ & $\mathrm{OH}$ & $\mathrm{H}$ & $\mathrm{H}$ & $\mathrm{H}$ & $\mathrm{H}$ & $\mathrm{H}$ & $\mathrm{H}$ \\
\hline $\begin{array}{l}\text { P. albenensis } \\
\text { P. auricula } \\
\text { P. farinosa } \\
\text { P. halleri }\end{array}$ & 7 & $\mathrm{H}$ & $\mathrm{H}$ & $\mathrm{H}$ & $\mathrm{OH}$ & $\mathrm{H}$ & $\mathrm{H}$ & $\mathrm{H}$ & $\mathrm{H}$ \\
\hline P. halleri & 8 & $\mathrm{H}$ & $\mathrm{OH}$ & $\mathrm{H}$ & $\mathrm{H}$ & $\mathrm{OH}$ & $\mathrm{H}$ & $\mathrm{H}$ & $\mathrm{H}$ \\
\hline P. farinosa & 9 & $\mathrm{H}$ & $\mathrm{H}$ & $\mathrm{H}$ & $\mathrm{H}$ & $\mathrm{H}$ & $\mathrm{OH}$ & $\mathrm{H}$ & $\mathrm{OH}$ \\
\hline
\end{tabular}

In the headspace around the leaves of these Primula species, 45 chemicals were identified, accounting for $97.6-99.7 \%$ of total volatiles (Table 3).

With the exception of $P$. albenensis, sesquiterpene hydrocarbons were the most represented $(96.9 \%, 86.0 \%, 85.5 \%$ for $P$. auricula, $P$. farinosa, $P$. halleri, respectively).

In $P$. albenensis 13 chemicals were identified. Five of them are exclusive to this species: paeonal (98.0\%), $\alpha$-thujene (0.1\%), terpinolene $(0.1 \%), 2^{\prime}$-hydroxyacetophenone $(0.2 \%)$ and $4^{\prime}$-methoxyacetophenone $(0.3 \%)$.
In $P$. auricula, the 19 substances emitted were almost entirely sesquiterpene hydrocarbons (96.9\%). The compounds exclusive to this species were present only in very low amounts: isocaryophyllene $(0.9 \%),(E)$ - $\beta$-farnesene $(0.4 \%)$ and $\gamma$-muurolene $(0.5 \%)$. The main components were $\beta$-caryophyllene $(28.1 \%)$, germacrene $D$ (22.3\%), $\beta$-elemene (14.3\%) and $\alpha$-cubebene (10.6\%).

A slight percentage of an oxygenated sesquiterpene, caryophyllene oxide $(0.9 \%)$, was also found.

In P. farinosa, 9 chemicals out of the 26 identified were exclusive to this species. Sesquiterpene hydrocarbons (86.0\%) were the prevailing volatiles. The main compounds were $\gamma$-gurjunene (20.6\%), also a connotative substance, germacrene D (18.7\%) and $\beta$-caryophyllene (16.7\%). Smaller quantities of non-terpene derivatives (7.8\%) and monoterpene hydrocarbons (4.5\%) were found.

In P. halleri, 17 volatiles were identified, 6 of which were typical of this species. In addition to sesquiterpenes (85.5\%), also non-terpene derivatives (8.1\%) were detected, as well as a small quantity of exclusive phenylpropanoid methyl eugenol (4\%). The compounds emitted in higher percentages were $\gamma$-himachalene (27\%), also exclusive of this species, germacrene D (13.1\%), $\beta$-elemene (12.2\%) and $\beta$-caryophyllene (9.1\%).

In the headspace around calyx and corolla of $P$. halleri, 26 chemicals were identified, accounting for $92.1-97.5 \%$ of total volatiles (Table 4). The substances emitted in higher percentages were non-terpenes derivatives (53.3\% and $60.8 \%$ in calyx and corolla, respectively) and sesquiterpene hydrocarbons (44.2\% and $25.3 \%$ in calyx and corolla, respectively), whereas oxygenated sesquiterpenes ( $2.2 \%$ only from corolla) and apocarotenoids ( 3.8 in corolla) were less represented. Monoterpene hydrocarbons, oxygenated monoterpenes and phenylpropanoids were completely absent.

The comparison between corolla and calyx showed that they have nine compounds in common. Only one, $\beta$-gurjunene (3.2\%), was specific to the calyx, while 16 chemicals were found only in corolla: inter alia, the oxygenated sesquiterpene kessane (2.2\%), and the apocarotenoid hexahydrofarnesylacetone.

\section{Discussion}

Morphology

Farinose exudate morphology is the same in all the species investigated and the base model of glandular hairs morphology does not show any variation. The size of each single cell of the

Table 2

Tissue flavonoids of Primula species.<smiles>[R]c1cc([R5])c2c(=O)c([R7])c(-c3ccc([R4])c([R3])c3[R2])oc2c1</smiles>

\begin{tabular}{|c|c|c|c|c|c|c|c|}
\hline Species & Ref. Num. & $\mathrm{R}_{1}$ & $\mathrm{R}_{2}$ & $\mathrm{R}_{3}$ & $\mathrm{R}_{4}$ & $\mathrm{R}_{5}$ & $\mathrm{R}_{6}$ \\
\hline \multirow[t]{3}{*}{ P. farinosa } & 10 & $\mathrm{H}$ & $\mathrm{OH}$ & O-Gal & $\mathrm{H}$ & $\mathrm{H}$ & $\mathrm{H}$ \\
\hline & 11 & ORha $(1 \rightarrow 3)$ Rha $(1 \rightarrow 6)$ Gal & $\mathrm{H}$ & $\mathrm{H}$ & $\mathrm{OH}$ & $\mathrm{OH}$ & $\mathrm{OH}$ \\
\hline & 12 & ORha $(1 \rightarrow 3)$ Rha $(1 \rightarrow 6)$ Glc & $\mathrm{H}$ & $\mathrm{H}$ & $\mathrm{OH}$ & $\mathrm{OH}$ & $\mathrm{OH}$ \\
\hline \multirow[t]{3}{*}{ P. halleri } & 13 & ORha $(1 \rightarrow 3) \operatorname{Rha}(1 \rightarrow 6)$ Gal & $\mathrm{H}$ & $\mathrm{OCH}_{3}$ & $\mathrm{OH}$ & $\mathrm{OH}$ & $\mathrm{OH}$ \\
\hline & 14 & ORha $(1 \rightarrow 3)$ Rha $(1 \rightarrow 6)$ Gal & $\mathrm{H}$ & $\mathrm{OH}$ & $\mathrm{OH}$ & $\mathrm{OH}$ & $\mathrm{OH}$ \\
\hline & 15 & $\operatorname{OGlc}(1 \rightarrow 2) \mathrm{Glc}(1 \rightarrow 6) \mathrm{Glc}$ & $\mathrm{H}$ & $\mathrm{H}$ & $\mathrm{OH}$ & $\mathrm{OH}$ & $\mathrm{OH}$ \\
\hline P. albenensis & 16 & $\mathrm{H}$ & $\mathrm{H}$ & $\mathrm{OH}$ & O-Glc & $\mathrm{H}$ & $\mathrm{H}$ \\
\hline \multirow[t]{2}{*}{ P. auricula } & & $\operatorname{OGlc}(1 \rightarrow 2) \mathrm{Glc}(1 \rightarrow 6) \mathrm{Glc}$ & $\mathrm{H}$ & $\mathrm{OCH}_{3}$ & $\mathrm{OH}$ & $\mathrm{OH}$ & $\mathrm{OH}$ \\
\hline & & $\operatorname{OGlc}(1 \rightarrow 2) \operatorname{Glc}(1 \rightarrow 6) \mathrm{Glc}$ & $\mathrm{H}$ & $\mathrm{OH}$ & $\mathrm{OH}$ & $\mathrm{OH}$ & $\mathrm{OH}$ \\
\hline
\end{tabular}


Table 3

Volatiles of fresh leaves of Primula species sampled by SPME

\begin{tabular}{|c|c|c|c|c|c|}
\hline Constituents & l.r.i. & P. albenensis leaves & P. auricula leaves & P. farinosa leaves & P. halleri leaves \\
\hline$\alpha$-Thujene & 928 & 0.1 & - & - & - \\
\hline p-Cymene & 1028 & - & - & 2.1 & - \\
\hline Limonene & 1032 & 0.1 & - & 0.9 & - \\
\hline$\gamma$-Terpinene & 1063 & 0.1 & - & 1.0 & - \\
\hline Terpinolene & 1090 & 0.1 & - & - & - \\
\hline p-Cymenene & 1091 & - & - & 0.5 & - \\
\hline Phenylethyl alcohol & 1112 & - & - & - & 4.4 \\
\hline 2'-Hydroxyacetophenone & 1164 & 0.2 & - & - & - \\
\hline$\alpha$-Cubebene & 1351 & - & 10.6 & 0.6 & - \\
\hline 4'-Methoxyacetophenone & 1352 & 0.3 & - & - & - \\
\hline$\alpha$-Copaene & 1377 & - & 5.1 & 2.3 & - \\
\hline$\beta$-Bourbonene & 1385 & 0.1 & 1.5 & - & - \\
\hline$\beta$-Cubebene & 1390 & - & - & 0.7 & - \\
\hline$\beta$-Elemene & 1392 & 0.1 & 14.3 & 5.7 & 12.2 \\
\hline Methyl eugenol & 1403 & - & - & - & 4.0 \\
\hline Isocaryophyllene & 1406 & - & 0.9 & - & - \\
\hline cis- $\alpha$-Bergamotene & 1416 & - & - & 0.8 & - \\
\hline$\beta$-Caryophyllene & 1419 & 0.3 & 28.1 & 16.7 & 9.1 \\
\hline$\beta$-Gurjunene & 1432 & - & - & - & 1.9 \\
\hline$\beta$-Copaene & 1433 & - & 0.9 & 1.1 & 1.3 \\
\hline trans- $\alpha$-Bergamotene & 1438 & - & - & 3.9 & 2.0 \\
\hline Paeonal & 1439 & 98.0 & - & - & - \\
\hline$\alpha$-Guaiene & 1441 & - & - & 2.0 & 1.3 \\
\hline$\alpha$-Himachalene & 1450 & - & - & 2.8 & - \\
\hline$\alpha$-Humulene & 1456 & - & 5.4 & 2.2 & - \\
\hline (E)- $\beta$-Farnesene & 1460 & - & 0.4 & - & - \\
\hline Alloaromadendrene & 1462 & - & - & 1.3 & 3.7 \\
\hline cis-Muurola-4(14),15-diene & 1463 & - & 0.5 & 0.6 & - \\
\hline (E)-2-Dodecen-1-ol & 1469 & - & - & - & 2.0 \\
\hline$\gamma$-Gurjunene & 1475 & - & - & 20.6 & - \\
\hline$\gamma$-Himachalene & 1478 & - & - & - & 27.0 \\
\hline$\gamma$-Muurolene & 1478 & - & 0.5 & - & - \\
\hline Germacrene D & 1482 & 0.1 & 22.3 & 18.7 & 13.1 \\
\hline$\beta$-Selinene & 1487 & - & 0.4 & - & 1.6 \\
\hline valencene & 1494 & - & 0.7 & 1.1 & 3.5 \\
\hline Viridiflorene & 1496 & - & - & 1.0 & - \\
\hline$\alpha$-Muurolene & 1502 & - & 0.5 & 0.7 & - \\
\hline$(E, E)$ - $\alpha$-Farnesene & 1506 & - & 2.5 & - & 6.8 \\
\hline trans- $\gamma$-Cadinene & 1513 & 0.1 & 0.5 & 0.8 & - \\
\hline 7-epi- $\alpha$-Selinene & 1520 & - & - & 0.4 & - \\
\hline$\delta$-Cadinene & 1524 & 0.1 & 1.8 & 2.0 & 2.0 \\
\hline Caryophyllene oxide & 1582 & - & 0.9 & - & - \\
\hline$n$-Hexadecane & 1600 & - & - & 7.8 & - \\
\hline$n$-Heptadecane & 1700 & - & - & - & 1.7 \\
\hline Monoterpene hydrocarbons & & 0.4 & 0.0 & 4.5 & 0.0 \\
\hline Sesquiterpene hydrocarbons & & 0.8 & 96.9 & 86.0 & 85.5 \\
\hline Oxygenated sesquiterpenes & & 0.0 & 0.9 & 0.0 & 0.0 \\
\hline Phenylpropanoids & & 0.0 & 0.0 & 0.0 & 4.0 \\
\hline Non-terpene derivatives & & 98.5 & 0.0 & 7.8 & 8.1 \\
\hline Total identified & & 99.7 & 97.8 & 98.3 & 97.6 \\
\hline
\end{tabular}

capitate trichome differs among species. Capitate trichomes can be divided into two types based on the dimension of stalk: longstalked capitate trichomes of $P$. albenensis and $P$. auricula and short-stalked capitate trichomes of $P$. farinosa and $P$. halleri.

Summarising, the characters that, in different combinations, define each species are: (1) distribution of farinas and glandular trichomes (uniform distribution on both leaf surfaces, upper surface and leaf margins, lower surface), (2) colour of farinas (white or yellow), (3) size and shape of glandular trichomes stalk and head.

\section{Epicuticular flavonoids}

Flavonoid compounds isolated on leaf surfaces are flavones hydroxylated in positions $5,7,8$ on the A ring and positions $2^{\prime}$, $4^{\prime}, 5^{\prime}$ on the $\mathrm{B}$ ring.

Flavone, 2'-hydroxyflavone and 4'-hydroxyflavone are present in all the species analysed.
On the qualitative point of view, $P$. halleri shows the richest profile, presenting flavones with hydroxylation in different positions, both on A and B rings. P. farinosa is characterised by 3,5-dihydroxyflavone, a new compound. P. albenensis and P. auricula do not show any distinctive compound.

The compounds found in the present work are exclusively hydroxylated, while those isolated in the past by Valant-Vetschera et al. (2009) and Wollenweber (1974) are partly methoxylated. Compared to the compounds isolated in the present study, in the works above mentioned, hydroxylation in position 5 in the A ring and in position $2^{\prime}$ on the $\mathrm{B}$ ring was the most frequent. The differences may be due to the different geographical origin of the specimens considered, as evidenced by literature (Marin et al., 2003).

Tissue flavonoids

Tissue flavonoids are flavonol-3-O-glycosydes based upon the aglycones kaempferol, quercetin or isorhamnetin, or flavones 
Table 4

Volatiles of $P$. halleri sampled by SPME.

\begin{tabular}{|c|c|c|c|c|}
\hline Constituents & 1.r.i. & Primula halleri leaves & Primula halleri calyxes & Primula halleri corollas \\
\hline 1-Undecene & 1093 & - & 5.2 & 2.5 \\
\hline Phenylethyl alcohol & 1112 & 4.4 & - & - \\
\hline$n$-Dodecane & 1200 & - & - & 1.1 \\
\hline Decanal & 1205 & - & - & 0.9 \\
\hline 1-Decanol & 1273 & - & - & 1.8 \\
\hline 1-Tridecene & 1293 & - & - & 5.9 \\
\hline 2-Undecanone & 1294 & - & - & 1.8 \\
\hline$n$-Tridecane & 1300 & - & - & 4.7 \\
\hline 1-Undecanol & 1371 & - & - & 4.5 \\
\hline$\beta$-Elemene & 1392 & 12.2 & 9.7 & 9.3 \\
\hline$n$-Tetradecane & 1400 & - & 18.1 & 7.6 \\
\hline Methyl eugenol & 1403 & 4.0 & - & - \\
\hline$\beta$-Caryophyllene & 1419 & 9.1 & - & 0.9 \\
\hline$\beta$-Gurjunene & 1432 & 1.9 & 3.2 & - \\
\hline$\beta$-Copaene & 1433 & 1.3 & - & - \\
\hline trans-a-Bergamotene & 1438 & 2.0 & - & - \\
\hline$\alpha$-Guaiene & 1441 & 1.3 & - & 0.6 \\
\hline Alloaromadendrene & 1462 & 3.7 & - & - \\
\hline (E)-2-Dodecen-1-ol & 1469 & 2.0 & 10.9 & 7.0 \\
\hline$\gamma$-Himachalene & 1478 & 27.0 & 26.5 & 9.5 \\
\hline Germacrene D & 1482 & 13.1 & - & - \\
\hline$\beta$-Selinene & 1487 & 1.6 & - & 2.1 \\
\hline 1-Pentadecene & 1491 & - & 3.1 & 1.7 \\
\hline Valencene & 1494 & 3.5 & 4.8 & 2.4 \\
\hline n-Pentadecane & 1500 & - & 12.1 & 16.5 \\
\hline$(E, E)$-a-Farnesene & 1506 & 6.8 & - & - \\
\hline 7-epi-a-Selinene & 1520 & - & - & 0.5 \\
\hline$\delta$-Cadinene & 1524 & 2.0 & - & - \\
\hline Kessane & 1531 & - & - & 2.2 \\
\hline 1-Tridecanol & 1570 & - & - & 0.6 \\
\hline 1-Hexadecene & 1591 & - & - & 2.0 \\
\hline$n$-Hexadecane & 1600 & - & 3.9 & 1.1 \\
\hline$n$-Heptadecane & 1700 & 1.7 & - & - \\
\hline$n$-Octadecane & 1800 & - & - & 1.1 \\
\hline Hexahydrofarnesylacetone & 1848 & - & - & 3.8 \\
\hline Sesquiterpene hydrocarbons & & 85.5 & 44.2 & 25.3 \\
\hline Oxygenated sesquiterpenes & & 0.0 & 0.0 & 2.2 \\
\hline Apocarotenoids & & 0.0 & 0.0 & 3.8 \\
\hline Phenylpropanoids & & 4.0 & 0.0 & 0.0 \\
\hline Non-terpene derivatives & & 8.1 & 53.3 & 60.8 \\
\hline Total identified & & 97.6 & 97.5 & 92.1 \\
\hline
\end{tabular}

showing a 3' or 4'-B ring glycosylation. The sugars are glucose, galactose and rhamnose, both as mono- and trisaccharides.

As shown in Table 2, each species is characterised by a different chromatographic profile, since there are no shared compounds among the four species investigated. More precisely, we noticed a great chemical affinity among the isolated compounds in each species. Flavonol derivatives show indeed the same type of aglycones (kaempferol, quercetin and isorhamnetin). Moreover, the triglycosylated compounds often have in common the linkage position on the aglycone and their structure: e.g. Rha-Rha-Gal triglycoside is present in both $P$. farinosa and $P$. halleri, while a Glc-gentiobioside triglycoside can be found both in $P$. auricula and $P$. halleri.

Only a few studies have investigated the tissue flavonoid composition of Primula genus (see 'Introduction' section). An overview of these studies has pointed out that the tissue flavonoids, which characterize flowers and leaves of the species belonging to Primula genus, are mostly flavonols based upon aglycones mainly represented by kaempferol, quercetin and isorhamnetin. Sometimes also limocitrin and tamarixin have been characterised. Among flavones, apigenin and luteolin are the most represented structures. Tissue flavonoids are mono-, di- and triglycosides, while the most represented sugars are glucose and rhamnose, often linked to form gentiobiose, neohesperidose and sophorose, as well as mannose, galactose and xylose. The most observed derivatives have the sugar moiety linked to the A ring or in the position 3, although P. spectabilis shows glycosylation almost exclusively on position 7, or seldom Cglycosilation on positions 6 and 8 .

Along with flavonols, flavone derivatives methoxylated, hydroxylated or glycosylated in position $7,4^{\prime}$ can be found. B ring glycosylation is less frequent and, so far, was observed in P. faberi only. In this study, though, it was also observed in $P$. albenensis and $P$. farinosa, both in positions $3^{\prime}$ and $4^{\prime}$.

We have discussed these results from a chemical point of view only, since from the existing data and those we obtained it is still almost impossible to determine the taxonomic relationships existing among the species.

This is mainly because the data we have are little and were obtained, from heterogeneous sources: the plants part inspected are sometimes the leaf, sometimes the flower, or, in some cases, the aerial parts.

\section{Volatiles}

We investigated the volatile compounds spontaneously emitted by glandular hairs of fresh leaves of the four species and, in the case of $P$. halleri, the compounds emitted by the flower parts (corolla and calyx) compared with the corresponding leaves.

The headspace leaf analysis showed that most of the 45 identified compounds are sesquiterpene hydrocarbons, but there are also non-terpene derivatives. 
In $P$. albenensis leaves, was found almost exclusively paeonal. In $P$. auricula leaves there were only sesquiterpenes. $P$. farinosa leaves contained also a small amount of monoterpene hydrocarbons (4.5\%), which are missing in the other species (only traces in $P$. albenensis). The phenylpropanoid methyl eugenol (4\%) was found only in $P$. halleri.

Concerning sesquiterpenes, $\beta$-caryophyllene, $\beta$-elemene and germacrene $\mathrm{D}$ were the main constituents shared by the bouquet of the species investigated.

Regarding leaf-flower comparison in $P$. halleri, 10 substances were identified in calyxes, 25 in corollas and 17 in leaves. Calyxes released non-terpene derivatives (53.3\%) and sesquiterpene hydrocarbons (44.2\%), whereas corollas emitted mostly non-terpene derivatives $(60.8 \%)$, followed by sesquiterpenes $(25.3 \%)$ and apocarotenoids $(3.8 \%)$.

In P. halleri, corolla produces 25 compounds, of which 13 are exclusive to the corolla itself, 5 can be found both in corolla and calyx and 4 compounds, $\beta$-elemene, (E)-2-dodecen-1-ol, $\gamma$-himachalene and valencene, are present in all the three parts considered.

\section{Experimental}

\section{Plant material}

Aerial parts of Primula species were sampled from randomly selected individuals collected in the Alps in Lombardy (Italy) and have been determined according to Banfi and Ferlinghetti (1993) and Pignatti (1982). Ten specimens have been taken out of every species considered and five leaves have been examined for each entity. Voucher specimens were deposited at the Dipartimento di Bioscienze, Università degli Studi di Milano (Italy) (Table 5). All the leaves were collected at flowering time.

\section{Morphological analysis}

Specimens for LM were preserved in a mixture of $37 \%$ formaldehyde, glacial acetic acid, 50\% ethanol (5:5:90 by volume). Pieces of leaves were then washed in distilled water and leaf sections of approximately $5 \mu \mathrm{m}$ were cut using a razor blade; alternatively, leaves were peeled by microscope tweezers. Epidermal tissues and leaf sections were cleared using sodium hypochlorite $5 \%$, washed in distilled water and mounted in a $90 \%$ solution of glycerine. Semi-permanent slides were examined and photographed with a LEICA DM light microscope.

For SEM morphological observations, leaves were air dehydrated and sputter-coated with gold. The samples were examined using a Cambridge Stereoscan 90 instrument.

\section{Phytochemical analysis}

Fresh leaves were rinsed with acetone in order to extract the epicuticular flavonoids. The extract was then chromatographed on a Sephadex LH-20 column, using $\mathrm{MeOH}-\mathrm{CH}_{3} \mathrm{COCH}_{3}(9: 1)$ as eluent for $P$. auricula e $P$. farinosa and $\mathrm{EtOH}$ as eluent for $P$. albenensis

\section{Table 5}

Primula samples.

\begin{tabular}{lll}
\hline Species $^{\mathrm{a}}$ & Locality of harvest & Herbarium No. \\
\hline P. albenensis & Monte Alben (Bergamo 1650-1750 m) & $\mathrm{P}_{\mathrm{B}}-101$ \\
P. auricula & Monte Alben (Bergamo 1650-1750 m) & $\mathrm{P}_{\mathrm{A}}-101$ \\
P. farinosa & Passo del Tonale (Brescia - 1850 m) & $\mathrm{P}_{\mathrm{R}}-101$ \\
P. halleri & Valle dell'Alpe (Sondrio - 2400 m) & $\mathrm{P}_{\mathrm{K}}-101$
\end{tabular}

${ }^{a}$ According to Banfi and Ferlinghetti; Pignatti. and $P$. halleri, to obtain fractions combined together according to TLC analyses [Silica $60 \mathrm{~F}_{254}$ gel-coated aluminium sheets; eluent: $\mathrm{C}_{6} \mathrm{H}_{5} \mathrm{CH}_{3}-\mathrm{CH}_{3} \mathrm{COOC}_{2} \mathrm{H}_{5}-\mathrm{HCOOH}$ (50:40:10)]. Some fractions were subjected to purification by flash column chromatography, using $n$-hexane-EtOAc at different ratio (Table 6). These techniques allowed the isolation of compounds 1-9. For the identification, the NMR and Mass spectrums of the isolated flavonoids have been compared to literature data (Looker et al., 1984; Park et al., 2007; Wollenweber et al., 1988b; Yoon et al., 2011).

After removing farinas, the dried and powdered leaves of Primula species were defatted with $n$-hexane and successively extracted with $\mathrm{CH}_{2} \mathrm{Cl}_{2}, \mathrm{CH}_{2} \mathrm{Cl}_{2}-\mathrm{MeOH}$ (9:1) and $\mathrm{MeOH}$, three times for each solvent. The $\mathrm{MeOH}$ extract was submitted to RP-HPLC on a Merck LiChrospher $100 \mathrm{RP}-18$ column $(5 \mu \mathrm{m}, 250 \times 4 \mathrm{~mm}$, flow rate $1.3 \mathrm{ml} / \mathrm{min})$ with binary gradient elution $\left[\mathrm{A}: \mathrm{H}_{2} \mathrm{O}(\mathrm{pH}\right.$ 3.5 with $\mathrm{HCl}$ ); $\mathrm{B}$ : $\mathrm{ACN}$; gradient: $0-10 \mathrm{~min} 88 \% \mathrm{~A}, 10-15 \mathrm{~min} 82 \%$ A, 30 min $55 \%$ A, 35-42 min $100 \%$ B, minimum re-equilibration time between two injections: $10 \mathrm{~min}]$. The detection range was $256-350 \mathrm{~nm}$. The concentration of samples was $100 \mathrm{mg} / \mathrm{ml}$ and the injection volume was $100 \mu \mathrm{l}$.

The analytical chromatographic analyses were performed with a Merck-Hitachi L 6200 system with a photo Diode Array Detector Hewlett Packard 1040, controlled by HP-Chemstation (Hewlett Packard) software. After removal of the solvent, the extracts were separately chromatographed on a Sephadex LH-20 column, using $\mathrm{MeOH}$ or EtOH as eluent, to obtain fractions, combined together according to TLC analyses [Silica $60 \mathrm{~F}_{254}$ gel-coated aluminium sheets; eluent: $n$ - $\mathrm{BuOH}-\mathrm{CH}_{3} \mathrm{COOH}-\mathrm{H}_{2} \mathrm{O}$ (60:15:25)]. The flavonoid-containing fractions, selected using NTS-PEG (Naturstoffreagenz A-Polyethylenglycol) as spray reagent, were submitted to RP-HPLC on a $\mathrm{C}_{18} \mu$-Bondapak column $(300 \times 7.8 \mathrm{~mm}$, flow rate $2.5 \mathrm{~mL} \mathrm{~min}^{-1}$ ) with $\mathrm{MeOH}-\mathrm{H}_{2} \mathrm{O}(40: 60)$ to yield compounds 1016.

All the isolated compounds were submitted to NMR spectroscopic measurements with Bruker AC $400(400 \mathrm{MHz})$ and Bruker Advance II $250(250 \mathrm{MHz})$ apparatus, using $\mathrm{CD}_{3} \mathrm{OD}$ or DMSO- $d_{6}$ as solvents, and the chemical shifts were expressed in $\delta$ (ppm) referring to solvent peaks: $\delta_{\mathrm{H}} 3.31$ or 2.49 and $\delta_{\mathrm{C}} 49.0$ or 39.5 , respectively. The HPLC-MS and UV-Vis spectra were performed on a HP 1090L instrument equipped with a Diode Array Detector, managed by a HP 9000 workstation interfaced with a HP 1100 MSD API-electrospray unit. Melting points (uncorrected) were determined with a Kofler apparatus. ESI mass spectra were recorded on Thermo Fischer Finningan LCQ Advantage Mass Spectometer.

\section{New compounds}

3,5-Dihydroxyflavone (1): amorphous white solid; ${ }^{1} \mathrm{H}$ NMR (250 MHz, DMSO-d6): $\delta 6.65(1 \mathrm{H}, \mathrm{d}, J=8.8 \mathrm{~Hz}, \mathrm{H}-6), 7.09(1 \mathrm{H}, \mathrm{dd}$, $J=8.8 \mathrm{~Hz} 8.8 \mathrm{~Hz}, \mathrm{H}-7), 7.25(1 \mathrm{H}, \mathrm{d}, J=8.8 \mathrm{~Hz}, \mathrm{H}-8), 7.61(2 \mathrm{H}, \mathrm{m}$, H-3' H-4' H-5'), 8.16 (2H, dd, $J=6.6 .8 \mathrm{~Hz} 1.8 \mathrm{~Hz}, \mathrm{H}-2^{\prime}$ H-6' $), 12.53$ $(1 \mathrm{H}, \mathrm{s}, \mathrm{OH}-5) ;{ }^{13} \mathrm{C}$ NMR $(62.5 \mathrm{MHz}, \mathrm{DMSO}-d 6): \delta 105.5$ (C-8), 110.1 (C-6), 110.7 (C-10), 126.7 (C-2' C-6'), 129.2 (C-3' C5'), 130.8 (C-1'), 132.3 (C-4'), 132.8 (C-7), 138.2 (C-3), 151.0 (C-9), 163.8 (C-2), 165.7 (C-5), 183.4 (C-4); ESI-MS: $254.0[\mathrm{M}+], 277.0$ $[\mathrm{M}+\mathrm{Na}+]$.

3'-O-( $\beta$-galactopyranosyl)-2'-hydroxyflavone (10): amorphous white solid; ${ }^{1} \mathrm{H}$ NMR (400 MHz, $\left.\mathrm{CD}_{3} \mathrm{OD}\right): \delta 3.45\left(1 \mathrm{H}, \mathrm{m}, \mathrm{H}-4^{\prime \prime}\right)$, $3.51\left(1 \mathrm{H}, \mathrm{m}, \mathrm{H}-5^{\prime \prime}\right), 3.53\left(1 \mathrm{H}, \mathrm{s}, \mathrm{H}-3^{\prime \prime}\right), 3.57\left(1 \mathrm{H}, \mathrm{m}, \mathrm{H}-2^{\prime \prime}\right), 3.76$ $\left(1 \mathrm{H}, \mathrm{dd}, J=7.9 \mathrm{~Hz} 1.7 \mathrm{~Hz}, \mathrm{H}-6^{\prime \prime} \mathrm{b}\right), 3.95(1 \mathrm{H}, \mathrm{dd}, J=7.9 \mathrm{~Hz} 1.0 \mathrm{~Hz}$, H-6"a), $4.98\left(1 \mathrm{H}, \mathrm{d}, J=7.9 \mathrm{~Hz}, \mathrm{H}-1^{\prime \prime}\right), 6.83(1 \mathrm{H}, \mathrm{s}, \mathrm{H}-3), 7.38(1 \mathrm{H}$, d, $\left.J=7.9 \mathrm{~Hz}, \mathrm{H}-4^{\prime}\right), 7.51(1 \mathrm{H}$, ddd, $J=7.9 \mathrm{~Hz} 7.0 \mathrm{~Hz} 1.0 \mathrm{~Hz}, \mathrm{H}-6)$, 7.58-7.53 (2H, m, H-5' and H-6'), $7.73(1 \mathrm{H}, \mathrm{dd}, J=8.5 \mathrm{~Hz} 1.0 \mathrm{~Hz}$, $\mathrm{H}-8), 7.83(1 \mathrm{H}$, ddd, $J=8.5 \mathrm{~Hz} 7.0 \mathrm{~Hz} 1.7 \mathrm{~Hz}, \mathrm{H}-7), 8.17(1 \mathrm{H}, \mathrm{dd}$, $J=7.9 \mathrm{~Hz} 1.7 \mathrm{~Hz}, \mathrm{H}-5) ;{ }^{13} \mathrm{C}$ NMR $\left(100 \mathrm{MHz}, \mathrm{CD}_{3} \mathrm{OD}\right): \delta 61.69$ 
Table 6

Separation of the epicuticular flavonoids.

\begin{tabular}{|c|c|c|c|c|c|c|c|}
\hline Species & Crude extract & Sephadex elution & Number of fractions obtained & Fraction analyzed & Flash elution Hex/EtOAc & Ref. Num. & Weight (mg) \\
\hline \multirow[t]{3}{*}{ P. albenensis } & Acetone & $\mathrm{EtOH}$ & 11 & Fraction 5 & - & 7 & 9 \\
\hline & & & & Fraction 6 & $6: 4$ & 6 & 14 \\
\hline & & & & Fraction 7 & $6: 4$ & 2 & 40 \\
\hline \multirow[t]{3}{*}{ P. auricula } & Acetone & MeOH-Acetone (9:1) & 8 & Fraction 1 & - & 7 & 10 \\
\hline & & & & Fraction 2 & $7: 3$ & 6 & 14 \\
\hline & & & & Fraction 3 & $7: 3$ & 2 & 160 \\
\hline \multirow[t]{6}{*}{ P. farinosa } & Acetone & MeOH-Acetone (9:1) & 10 & Fraction 4 & - & 7 & 12 \\
\hline & & & & Fraction 5 & $7: 3$ & 2 & 218 \\
\hline & & & & & & 6 & 15 \\
\hline & & & & Fraction 6 & $8: 2$ & 3 & 6 \\
\hline & & & & Fraction 8 & $8: 2$ & 1 & 5 \\
\hline & & & & Fraction 9 & - & 9 & 6 \\
\hline \multirow[t]{7}{*}{ P. halleri } & Acetone & EtOH & 11 & Fraction 2 & - & 7 & 10 \\
\hline & & & & Fraction 3 & $2: 3$ & 2 & 68.5 \\
\hline & & & & & & 6 & 12 \\
\hline & & & & Fraction 6 & $2: 3$ & 3 & 10 \\
\hline & & & & & & 8 & 11.5 \\
\hline & & & & Fraction 8 & $1: 1$ & 4 & 16 \\
\hline & & & & & & 5 & 115 \\
\hline
\end{tabular}

(C-6"), 70.56 (C-4" ), 74.05 (C-2"), 76.83 (C-3"), 77.75 (C-5"), 102.5 $\left(\mathrm{C}-1^{\prime \prime}\right), 106.1$ (C-3), $114.3\left(\mathrm{C}-6^{\prime}\right), 117.3\left(\mathrm{C}-4^{\prime}\right), 118.7(\mathrm{C}-8), 119.2$ (C-5'), 124.7 (C-10), 125.4 (C-5), 126.0 (C-6), 126.7 (C-1'), 134.9 (C-7), 148.0 (C-2'), 149.4 (C-3'), 156.7 (C-9), 165.2 (C-2), 179.8 (C-4); ESI-MS: ESI-MS: $439.2\left[\mathrm{M}+\mathrm{Na}^{+}\right], 855.0\left[2 \mathrm{M}+\mathrm{Na}^{+}\right]$.

Isorhamnetin 3-O- $\alpha$-rhamnopyranosyl-( $1 \rightarrow 3)-0$-[ $\alpha$-rhamnopyr-

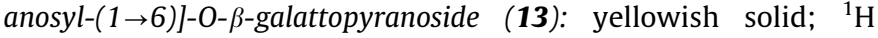
NMR (250 MHz, DMSO-d $\left.d_{6}\right): \delta 0.98\left(3 \mathrm{H}, \mathrm{d}, 6.1 \mathrm{~Hz}, \mathrm{H}-6^{\prime \prime \prime \prime}\right), \delta 1.05$ $\left(3 \mathrm{H}, \mathrm{d}, 6.0 \mathrm{~Hz}, \mathrm{H}-6^{\prime \prime \prime}\right), 3.13\left(1 \mathrm{H}, \mathrm{m}, \mathrm{H}-4^{\prime \prime \prime}\right), 3.15\left(1 \mathrm{H}, \mathrm{m}, \mathrm{H}-4^{\prime \prime \prime \prime}\right)$, $3.23\left(1 \mathrm{H}, \mathrm{m}, \mathrm{H}-6 \mathrm{~b}^{\prime \prime}\right), 3.31\left(1 \mathrm{H}, \mathrm{m}, \mathrm{H}-2^{\prime \prime \prime}\right), 3.33$ (1H, m, H-5 $\left.5^{\prime \prime \prime}\right), 3.35$ $\left(1 \mathrm{H}, \mathrm{m}, \mathrm{H}-6^{\prime \prime} \mathrm{a}\right), 3.43\left(1 \mathrm{H}, \mathrm{m}, \mathrm{H}-3^{\prime \prime \prime}\right), 3.52\left(1 \mathrm{H}, \mathrm{m}, \mathrm{H}-3^{\prime \prime \prime \prime}\right), 3.54(1 \mathrm{H}$, $\left.\mathrm{m}, \mathrm{H}-5^{\prime \prime}\right), 3.58\left(1 \mathrm{H}, \mathrm{m}, \mathrm{H}-4^{\prime \prime}\right), 3.61\left(1 \mathrm{H}, \mathrm{m}, \mathrm{H}-2^{\prime \prime}\right), 3.63(1 \mathrm{H}, \mathrm{m}, \mathrm{H}-$ $\left.5^{\prime \prime \prime \prime}\right), 3.79\left(3 \mathrm{H}, \mathrm{s},-\mathrm{OCH}_{3}\right), 3.81\left(1 \mathrm{H}, \mathrm{m}, \mathrm{H}-2^{\prime \prime \prime \prime}\right), 3.84\left(1 \mathrm{H}, \mathrm{m}, \mathrm{H}-3^{\prime \prime}\right)$, $4.41\left(1 \mathrm{H}\right.$, brs, $\left.\mathrm{H}-1^{\prime \prime \prime}\right), 4.72\left(1 \mathrm{H}\right.$, brs, $\left.\mathrm{H}-1^{\prime \prime \prime \prime}\right), 5.25(1 \mathrm{H}, \mathrm{d}, J=7.1 \mathrm{~Hz}$, $\left.\mathrm{H}-1^{\prime \prime}\right), 6.07(1 \mathrm{H}, \mathrm{d}, J=1.9 \mathrm{~Hz}, \mathrm{H}-6), 6.34(1 \mathrm{H}, \mathrm{d}, J=1.9 \mathrm{~Hz}, \mathrm{H}-8)$, $7.92\left(1 \mathrm{H}\right.$, brs, $\left.\mathrm{H}-2^{\prime}\right), 7.39\left(1 \mathrm{H}\right.$, brd, $\left.J=8.8 \mathrm{~Hz}, \mathrm{H}-6^{\prime}\right), 6.80(1 \mathrm{H}, \mathrm{d}$, $\left.J=2.0 \mathrm{~Hz}, \mathrm{H}-5^{\prime}\right) ;{ }^{13} \mathrm{C}$ NMR $\left(62.5 \mathrm{MHz}\right.$, DMSO-d $\left.{ }_{6}\right): \delta 17.7\left(\mathrm{C}-6^{\prime \prime \prime \prime}\right)$, $17.8\left(\mathrm{C}-6^{\prime \prime \prime}\right), 55.8\left(-\mathrm{OCH}_{3}\right) 65.1\left(\mathrm{C}-6^{\prime \prime}\right), 67.9\left(\mathrm{C}-4^{\prime \prime}\right), 68.3\left(\mathrm{C}-5^{\prime \prime \prime}\right)$,

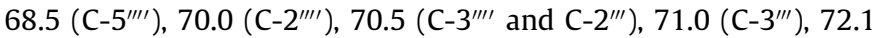

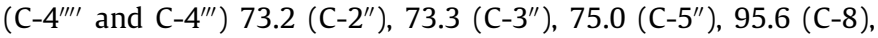

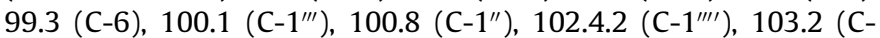
10), $113.2\left(\mathrm{C}-2^{\prime}\right), 115.2\left(\mathrm{C}-5^{\prime}\right), 120.7\left(\mathrm{C}-1^{\prime}\right), 121.6\left(\mathrm{C}-6^{\prime}\right), 132.4(\mathrm{C}-$ 3), 138.9 (C-3'), 147.1 (C-4'), 152.1 (C-2), 153.7 (C-9), 157.4 (C-5), 160.6 (C-7), 174.6 (C-4); ESI-MS: $770.2\left[\mathrm{M}^{+}\right], 793.2\left[\mathrm{M}+\mathrm{Na}^{+}\right]$.

Quercetin 3-O- $\alpha$-rhamnopyranosyl- $(1 \rightarrow 3)-0$-[ $\alpha$-rhamnopyrano-

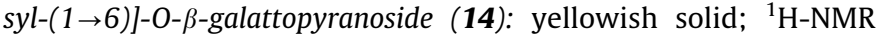
$\left(250 \mathrm{MHz}, \mathrm{DMSO}-\mathrm{d}_{6}\right): \delta 0.98\left(3 \mathrm{H}, \mathrm{d}, 5.8 \mathrm{~Hz}, \mathrm{H}-6^{\prime \prime \prime \prime}\right), \delta 1.07(3 \mathrm{H}$, d, $\left.6.1 \mathrm{~Hz}, \mathrm{H}-6^{\prime \prime \prime}\right), 3.12\left(1 \mathrm{H}, \mathrm{m}, \mathrm{H}-4^{\prime \prime \prime}\right), 3.15\left(1 \mathrm{H}, \mathrm{m}, \mathrm{H}-4^{\prime \prime \prime \prime}\right), 3.21$ $\left(1 \mathrm{H}, \mathrm{m}, \mathrm{H}-6 \mathrm{~b}^{\prime \prime}\right), 3.32\left(1 \mathrm{H}, \mathrm{m}, \mathrm{H}-2^{\prime \prime \prime}\right), 3.34\left(1 \mathrm{H}, \mathrm{m}, \mathrm{H}-5^{\prime \prime \prime}\right), 3.35$ (1H, m, H-6"a), $3.43\left(1 \mathrm{H}, \mathrm{m}, \mathrm{H}-3^{\prime \prime \prime}\right), 3.51\left(1 \mathrm{H}, \mathrm{m}, \mathrm{H}-3^{\prime \prime \prime \prime}\right), 3.56$ $\left(1 \mathrm{H}, \mathrm{m}, \mathrm{H}-5^{\prime \prime}\right), 3.58\left(1 \mathrm{H}, \mathrm{m}, \mathrm{H}-4^{\prime \prime}\right), 3.62\left(1 \mathrm{H}, \mathrm{m}, \mathrm{H}-2^{\prime \prime}\right), 3.63(1 \mathrm{H}$, $\left.\mathrm{m}, \mathrm{H}-5^{\prime \prime \prime \prime}\right), 3.80\left(1 \mathrm{H}, \mathrm{m}, \mathrm{H}-2^{\prime \prime \prime \prime}\right), 3.83\left(1 \mathrm{H}, \mathrm{m}, \mathrm{H}-3^{\prime \prime}\right), 4.40(1 \mathrm{H}$,

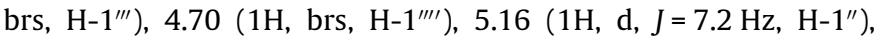
$6.05(1 \mathrm{H}, \mathrm{d}, J=1.9 \mathrm{~Hz}, \mathrm{H}-6), 6.36(1 \mathrm{H}, \mathrm{d}, J=1.9 \mathrm{~Hz}, \mathrm{H}-8), 6.71$ $\left(1 \mathrm{H}, \mathrm{d}, J=8.5 \mathrm{~Hz}, \mathrm{H}-5^{\prime}\right), 7.46\left(1 \mathrm{H}, \mathrm{d}, J=2.0 \mathrm{~Hz}, \mathrm{H}-2^{\prime}\right), 7.59(1 \mathrm{H}$, $\left.\mathrm{d}, J=8.5 \mathrm{~Hz} 2.0 \mathrm{~Hz}, \mathrm{H}-6^{\prime}\right) ;{ }^{13} \mathrm{C}$ NMR $\left(62.5 \mathrm{MHz}\right.$, DMSO- $\left.d_{6}\right): \delta$ $17.7\left(\mathrm{C}-6^{\prime \prime \prime \prime}\right), 17.9\left(\mathrm{C}-6^{\prime \prime \prime}\right), 65.3\left(\mathrm{C}-6^{\prime \prime}\right), 68.1\left(\mathrm{C}-4^{\prime \prime}\right), 68.3\left(\mathrm{C}-5^{\prime \prime \prime}\right)$, $68.6\left(\mathrm{C}-5^{\prime \prime \prime \prime}\right), 70.0\left(\mathrm{C}-2^{\prime \prime \prime \prime}\right), 70.5$ (C-3 $3^{\prime \prime \prime \prime}$ and $\left.\mathrm{C}-2^{\prime \prime \prime}\right), 71.0\left(\mathrm{C}-3^{\prime \prime \prime}\right)$, $72.2\left(\mathrm{C}-4^{\prime \prime \prime \prime}, \mathrm{C}-4^{\prime \prime \prime}\right.$ and $\left.\mathrm{C}-2^{\prime \prime}\right), 73.3\left(\mathrm{C}-3^{\prime \prime}\right), 74.9\left(\mathrm{C}-5^{\prime \prime}\right), 94.6(\mathrm{C}-8)$, 99.3 (C-6), 100.1 (C-1"'), $100.6\left(\mathrm{C}-1^{\prime \prime}\right), 102.4\left(\mathrm{C}-1^{\prime \prime \prime \prime}\right), 103.2(\mathrm{C}-$ 10), 115.1 (C-5'), 115.3 (C-2'), 120.3 (C-1'), $121.9\left(\mathrm{C}-6^{\prime}\right), 133.1$ (C-3), 145.2 (C-3'), 149.9 (C-4'), 150.0 (C-2), 155.4 (C-9), 156.9 (C-5), 160.8 (C-7), 175.9 (C-4); $\quad$ ESI-MS: $756.2 \quad\left[\mathrm{M}^{+}\right], \quad 779.2$ $\left[\mathrm{M}+\mathrm{Na}^{+}\right]$.

\section{Volatile compounds}

The solid phase microextraction (SPME) was carried out by Supelco SPME devices coated with polydimethylsiloxane (PDMS, $100 \mu \mathrm{m}$ ), used for sampling the headspace of Primula aerial parts placed into a $100 \mathrm{ml}$ glass septum vial and allowed to equilibrate for $30 \mathrm{~min}$. After the equilibration time, the fiber was exposed to the headspace for $30 \mathrm{~min}$ at room temperature. At the end of sampling, the fiber was withdrawn into the needle and transferred to the injection port of the GC or GC-MS system, operating as follows.

The GC analyses were accomplished with a HP-5890 Series II instrument equipped with HP-WAX and HP-5 capillary columns (30 $\mathrm{m} \times 0.25 \mathrm{~mm}, 0.25 \mu \mathrm{m}$ film thickness), and with the following conditions: temperature program $60^{\circ} \mathrm{C}$ for $10 \mathrm{~min}$, followed by an increase of $5^{\circ} \mathrm{C} / \mathrm{min}$ to $220^{\circ} \mathrm{C}$; injector and detector temperatures at $250{ }^{\circ} \mathrm{C}$; carrier gas helium $(2 \mathrm{ml} / \mathrm{min})$; splitless injection; detector dual FID.

For both the columns, identification of the chemicals was performed by comparison of their retention times with those of pure authentic samples and by means of their Linear Retention Indices (LRI) relative to the series of $n$-hydrocarbons.

GC-EIMS analyses were performed with a Varian CP-3800 gaschromatograph equipped with a HP-5 ms capillary column $(30 \mathrm{~m} \times 0.25 \mathrm{~mm}$; coating thickness $0.25 \mu \mathrm{m})$ and a Varian Saturn 2000 ion trap mass detector. The analytical conditions were the following: injector and transfer line temperatures 250 and $240{ }^{\circ} \mathrm{C}$ respectively; oven temperature from 60 to $240{ }^{\circ} \mathrm{C}$ at $3{ }^{\circ} \mathrm{C} / \mathrm{min}$; carrier gas helium at $1 \mathrm{ml} / \mathrm{min}$; splitless injection. Identification of the constituents was based on comparison of their retention times with those of authentic samples, comparing their Linear Retention Indices relative to the series of $n$-hydrocarbons, and on computer matching against commercial mass spectra (NIST 98 and ADAMS 95) and those of our library, built up from pure substances and components of known essential oils and MS literature data [346 (Stenhagen et al., 1974); 347 (Massada, 1976); 348 (Jennings and Shibamoto, 1980); 364 (Swigar and Silverstein, 1981); 349 (Davies, 1990); 350 (Adams, 1995)]. Moreover, the molecular weights of all the identified substances were confirmed by GC-CIMS, using $\mathrm{MeOH}$ as $\mathrm{Cl}$ ionizing gas.

\section{References}

Abubakar, A., Ogbadoyi, E.O., Okogun, J.I., Gbodi, T.I., Ibikunle, G.F., 2012. The identification of putative antitrypanosomal compounds in Tridax procumbens extracts. Int. J. Med. Arom. Plants 2, 185-194. 
Adams, R.P., 1995. Identification of Essential Oil Components by Gas Chromatography-Mass Spectroscopy. Allured Publ. Corp, Carol Stream, Illinois.

Ahmad, V.U., Shah, M.G., Mohammad, F.V., Baqai, F.T., 1993. Macrophyllicin, a saponin from Primula macrophylla. Phytochemistry 32, 1543-1547.

Ahmad, V.U., Shah, M.G., Mohammad, F.V., Ismail, N., Noorwala, M., 1991. Macrophylloside, a flavone glucoside from Primula macrophylla. Phytochemistry 30, 4206-4208.

Banfi, E., Ferlinghetti, R., 1993. Primula albenensis sp. nov., una nuova entità de sottogenere Auriculastrum nelle Prealpi Bergamasche (Alpi sudorientali, Lombardia). Webbia 47, 203-212.

Bouillant, M., Wollenweber, E., Chopin, J., 1971. Demonstration of 2 'hydroxyflavone and 2',5-dihydroxyflavone in the primrose Primula florindae. C.R. Acad. Sci. Ser. D 273, 1629-1631.

Budzianowski, J., Morozowska, M., Wesołowska, M., 2005. Lipophilic flavones of Primula veris L. from field cultivation and in vitro cultures. Phytochemistry 66, 1033-1039.

Bhutia, T.D., Valant-Vetschera, K.M., Brecker, L., 2013. Orphan flavonoids and dihydrochalcones from Primula exudates. Nat. Prod. Commun. 8, 1081-1084.

Bhutia, T.D., Valant-Vetschera, K.M., Adlassnig, W., Brecker, L., 2012. Flavonoids in selected Primula spp.: bridging micromorphology with chemodiversity. Nat. Prod. Commun. 7, 1469-1473.

Bhutia, T.D., Valant-Vetschera, K.M., 2012. Diversification of exudate flavonoid profiles in further Primula spp. Nat. Prod. Commun. 7, 587-589.

Bhutia, T.D., Adlassnig, W., Brecker, L., Valant-Vetschera, K., 2011. A study on exudates and micromorphology of Primula. Planta Med. 77, 1333.

Calis, I., 1992. Triterpene saponins from Primula veris subsp. macrocalyx and Primula elatior subsp. meyeri. J. Nat. Prod. 55, 1299-1306.

Coran, S.A., Mulas, S., 2012. Validated determination of primulasaponins in primula root by a high-performance-thin-layer-chromatography densitometric approach. J. Pharm. Biomed. Anal. 70, 647-651.

Davies, N.W., 1990. Gas chromatographic retention indices of monoterpenes and sesquiterpenes on methyl silicon and Carbowax 20M phases. J. Chromatogr. $503,1-24$.

Della Loggia, R., 1993. Piante medicinali per infusi e tisane. Org. Ed. Medico Farmaceutica, Milano.

Fico, G., Rodondi, G., Flamini, G., Passarella, D., Tomè, F., 2007. Comparative phytochemical and morphological analyses of three Italian Primula species. Phytochemistry 68, 1683-1691.

Geissman, T.A., 1962. The Chemistry of Flavonoid Compounds. Pergamon Press, p. 415.

Harborne, J.B., 1968. Comparative biochemistry of the flavonoids-VII Phytochemistry 7, 1215-1230.

Higuchi, Y., Kitajima, A., Ogiwara, I., Hakoda, N., Shimura, I., 1999. Morphological charachteristics of trichomes of primin-secreting and primin-free cultivars in Primula obconica. J. Jap. Soc. Hort. Sci. 68 (3), 614-621.

Huck, C.W., Huber, C.G., Ongania, K.H., Bonn, G.K., 2000. Isolation and characterization of methoxylated flavones in the flowers of Primula veris by liquid chromatography and mass spectrometry. J. Chromatogr., A. 870, 453 462.

Huck, C.W., Huber, C.G., Lagoja, I.M., Ongania, K.-H., Scherz, H., Bonn, G.K., Popp, M., 1999. Isolation and structural elucidation of $3^{\prime}, 4^{\prime}, 5^{\prime}$-trimethoxyflavone from the flowers of Primula veris. Planta Med. 65, 491.

Jennings, W., Shibamoto, T., 1980. Qualitative Analysis of Flavour and Fragrance Volatiles by Glass Capillary Chromatography. Academic Press, New York.

Karl, C., Müller, G., Pedersen, P.A., 1981. Flavonoids in the flowers of Primula officinalis. Planta Med. 41, 96-99.

Kazuma, K., Noda, N., Suzuki, M., 2003. Malonylated flavonol glycosides from the petals of Clitoria ternatea. Phytochemistry 62, 229-237.

Lindstedt, G., 1950. Constituents of pine heartwood. The heartwood of Pinus aristata Engelm. Acta Chem. Scand. 4, 55-59.

Lindstedt, G., 1949a. Constituents of pine heartwood. The heartwood of Pinus monticola Doug. Acta Chem. Scand. 3, 1147-1152.

Lindstedt, G., 1949b. Constituents of pine heartwood. The heartwood of Pinus excelsa Wall. Acta Chem. Scand. 3, 1375-1380.

Looker, J.H., Edman, J.R., Kingsbury, C.A., 1984. 5,8-Quinoflavone. Synthesis and addition reactions. J. Org. Chem. 49, 645-649.
Marin, P.D., Grayer, R.J., Kite, G.C., Matevski, V., 2003. External leaf flavonoids of Thymus species from Macedonia. Biochem. Syst. Ecol. 31, 1291-1307.

Massada, Y., 1976. Analysis of Essential Oils by Gas Chromatography and Mass Spectrometry. J. Wiley \& Sons, New York.

Morozowska, M., Wesołowska, M., 2004. In vitro clonal propagation of Primula veris L. and preliminary phytochemical analysis. Acta Biol. Cracov. Ser. Bot. 46, 169175.

Müller, A., Ganzera, M., Stuppner, H., 2006. Analysis of phenolic glycosides and saponins in Primula elatior and Primula veris (primula root) by liquid chromatography, evaporative light scattering detection and mass spectrometry. J. Chromatogr. A 1112, 218-223.

Nahrstedt, A., Hungeling, M., Petereit, F., 2006. Flavonoids from Acalypha indica. Fitoterapia 77, 484-486.

Okršlar, V., Plaper, I., Kovač, M., Erjavec, A., Obermajer, T., Rebec, A., Ravnikar, M., Žel, J., 2007. Saponins in tissue culture of Primula veris L. In Vitro Cell. Dev. 43, 644-651.

Park, Y., Moon, B.-H., Lee, E., Lee, Y., Yoon, Y., Ahn, J.-H., Lim, Y., 2007. Spectral assignments and reference data. Magn. Reson. Chem. 45, 674-679.

Petitjean-Freytet, C., 1993. La fleur de primevère: étude comparée de Primula veris L. et Primula elatior (L) L. Plant. Med. Phytother. 26, 27-35.

Pignatti, S., 1982. Flora d'Italia. Edagricole, Bologna.

Qu, G., Ouyang, J., Kong, D., Du, S., 2008. Studies on chemical constituents of Primula maximowiczii Regel II. Chin. Pharm. J. 43, 1300-1304.

Ruiz, E., Donoso, C., González, F., Becerra, J., Marticorena, C., Silva, M., 1999. Phenetic relationships between Juan Fernandez and continental chilean species of Sophora (Fabaceae) based on flavonoid patterns. Bol. Soc. Chil. Quím. 44, 351356.

Saito, N., Yoda, K., Haruyama, H., Kuwano, H., Honda, T., 1990. Structure determination of a violet-blue flower flavonoid quercetin 3-glucosyl$(1 \rightarrow 2)$ gentiobioside from Primula polyantha. Heterocycles 30, 759-764.

Stenhagen, E., Abrahamsson, S., McLafferty, F.W., 1974. Registry of Mass Spectral Data. J. Wiley \& Sons, New York.

Swigar, A.A., Silverstein, R.M., 1981. Monoterpenes. Aldrich Chem. Comp, Milwaukee.

Tokalov, S.V., Kind, B., Wollenweber, E., Gutzeit, H.O., 2004. Biological effects of epicuticolar flavonoids from Primula denticulata on human leukemia cells. J. Agric. Food Chem. 52, 239-245.

Valant-Vetschera, K.M., Buthia, T.D., Wollenweber, E., 2009. Exudate flavonoids of Primula spp: structural and biogenetic chemodiversity. Nat. Prod. Commun. 4, 365-370.

Vitalini, S., Flamini, G., Valaguzza, A., Rodondi, G., Iriti, M., Fico, G., 2011. Primula spectabilis Tratt. aerial parts: morphology, volatile compounds and flavonoids. Phytochemistry $72,1371-1378$.

Weller, L.E., Redemann, C.T., Gottshall, R.Y., Roberts, J.M., Lucas, E.H., Sell, H.M. 1953. Antibacterial substances in seed plants active against tubercule Bacilli. Antibiot. Chemother. 3, 603-606.

Wollenweber, E., Iinuma, M., Tanaka, T., Mizuno, M., 1990. 5-Hydroxy-6,2' methoxyflavone from Primula denticulata. Phytochemistry 29, 633-637.

Wollenweber, E., Mann, K., Iinuma, M., Tanaka, T., Mizuno, M., 1989. 5,2',5'Trihydroxyflavone and 2', $\beta$-dihydroxychalcone from Primula pulverulenta. Phytochemistry 28, 295-296.

Wollenweber, E., Mann, K., Iinuma, M., Tanaka, T., Mizuno, M., 1988a. 8,2'Dihydroxyflavone from Primula pulverulenta. Phytochemistry 27, 1483-1486.

Wollenweber, E., Mann, K., Iinuma, M., Tanaka, T., Mizuno, M., 1988b. 2',5'dihydroxyflavone and its 5'-acetate - novel compounds from the farinose exudate of Primula. Z. für Natürforsch. 43, 305-307.

Wollenweber, E., 1974. Die verbreitung spezifischer Flavone in der Gattung Primula. Biochem. Physiol. Pflanzen 166, 419-424.

Yoon, H., Eom, S., Hyun, H., Jo, G., Hwang, D., Lee, S., Yong, Y., Park, J.C., Lee, Y.H., Lim, Y., 2011. ${ }^{1} \mathrm{H}$ and ${ }^{13} \mathrm{C}$ NMR data on hydroxy/methoxy flavonoids and the effects of substituents on chemical shifts. Bull. Korean Chem. Soc. 32, 2101-2104.

Zhang, G., Bao, X., Xiao, Z., 1993. Chemical constituents of Primula faberi Oliver. Huaxi Yaoxue Zazhi 8, 189-190.

Zhao, G.Q., Xia, J.J., Dong, J.X., 2007. Glycosides from flowers of Jasminum officinale L. var. grandiflorum. Acta Pharm. Sin. 42, 1066-1069. 